University of Nebraska - Lincoln

DigitalCommons@University of Nebraska - Lincoln

Management Department Faculty Publications

Management Department

2011

\title{
Mentoring Impact on Leader Efficacy Development: A Field Experiment
}

\author{
Paul B. Lester \\ U.S. Army's Comprehensive Soldier Fitness Directorate, paul.lester@us.army.mil \\ Sean T. Hannah \\ United States Military Academy \\ Peter D. Harms \\ University of Nebraska - Lincoln, pharms@gmail.com \\ Gretchen R. Vogelgesang \\ Federal Management Partners, gretchen.lester@sjsu.edu \\ Bruce J. Avolio \\ University of Washington
}

Follow this and additional works at: https://digitalcommons.unl.edu/managementfacpub

Part of the Management Sciences and Quantitative Methods Commons

Lester, Paul B.; Hannah, Sean T.; Harms, Peter D.; Vogelgesang, Gretchen R.; and Avolio, Bruce J., "Mentoring Impact on Leader Efficacy Development: A Field Experiment" (2011). Management Department Faculty Publications. 80.

https://digitalcommons.unl.edu/managementfacpub/80

This Article is brought to you for free and open access by the Management Department at DigitalCommons@University of Nebraska - Lincoln. It has been accepted for inclusion in Management Department Faculty Publications by an authorized administrator of DigitalCommons@University of Nebraska - Lincoln. 


\title{
Mentoring Impact on Leader Efficacy Development: A Field Experiment
}

\author{
PAUL B. LESTER \\ U.S. Army's Comprehensive Soldier Fitness Directorate \\ SEAN T. HANNAH \\ United States Military Academy, West Point \\ P. D. HARMS \\ University of Nebraska, Lincoln \\ GRETCHEN R. VOGELGESANG \\ Federal Management Partners \\ BRUCE J. AVOLIO \\ University of Washington
}

\begin{abstract}
While practitioners and scholars tout the importance of mentorship in leader development, few studies have empirically determined whether mentoring actually positively impacts a leader's development, and if so, in what ways. In a longitudinal field experiment, we examined how a targeted mentorship program that unfolded over 6 months enhanced the development of protégés' leader efficacy and performance. Results showed that the targeted mentorship intervention increased protégés' level of leader efficacy more than a comparison intervention that was based on a more eclectic leadership education program delivered in a group setting. Leader efficacy then predicted rated leader performance. Both protégés' preferences for feedback and trust in the mentor served as important moderators in contributing to the development of leader efficacy. Findings from this longitudinal field experiment could be used by educational institutions and other organizations to enhance their mentorship programs in content, focus, and evaluation of impact.
\end{abstract}

According to Eby (2010: 505), "[m]entoring refers to a developmentally oriented interpersonal relationship that is typically between a more experienced individual (i.e., the mentor) and a less experienced individual (i.e., the protégé)." A number of scholars and certainly numerous practitioners have touted the importance of mentorship in promoting leader development (e.g., London, 2002; McCauley \& Van Velsor, 2004). Indeed, the assumption that having a good mentor is essential to one's career success as a leader is ubiquitous in career counseling, yet there is little empirical evidence to justify this assumption. We are similarly aware of no published research providing specific evidence that having a mentor actually enhances one's development as a leader, although meta-analytic research suggests that mentorship can lead to behavioral, attitudinal, and performance change in general (e.g., Eby, Allen, Evans, Ng, \& DuBois, 2008; Gentry, Weber, \& Sadri, 2008).

Therefore, we believe that effective mentoring tailored to the developmental needs of the protégés should enhance and accelerate their development as leaders. However, there is debate on the form and function of mentoring within the mentorship literature. For example, prior research suggests that formal mentorship programs that compel participation are largely ineffective, that the most effective mentoring relationships occur organically within an organization, and that little to 
no oversight or structure is required by organizational leadership (Johnson, 2007; Johnson \& Andersen, 2010). Such conclusions offer little to organizations that want to invest in organizationally endorsed mentorship programs as a way to develop their leaders. Our intent here is to empirically examine these issues by way of a longitudinal field study to shed light on whether and how targeted mentorship may serve as an effective leader development intervention.

That we know relatively little about the effectiveness of mentorship as a leader development intervention is not necessarily surprising insofar as it parallels our lack of knowledge of the broader domain of leadership development in general. For example, DeRue and Wellman (2009: 868) concluded from their analysis of the leader development literature that ". . .we know very little about the processes by which individuals develop the skills and capabilities necessary to lead effectively." Despite the limited amount of research that has focused on the efficacy of leader development efforts, there is some independent and metaanalytic research that offers preliminary evidence supporting various training interventions focused on enhancing management and leadership development outcomes (Arthur, Bennett, Edens, \& Bell, 2003; Burke \& Day, 1986; Collins \& Holton, 2004). For instance, Burke and Day (1986) concluded from their meta-analysis that "general management training was shown to be very effective, on the average, in improving performance as measured by objective results" (241-242). In a more recent meta-analysis, Collins and Holton (2004) reported effect sizes of 0.35-1.37 (d statistics; Cohen, 1988) for the effectiveness of leadership training, depending on type of outcome. Likewise, Avolio, Reichard, Hannah, Walumbwa, and Chan (2009) reported similar effect sizes and ranges for a broader range of leadership development interventions. Collins and Holton (2004) concluded that leaders could benefit from training and developmental interventions given that "the right development is offered to the right leaders" (217).

Based on the above evidence, we suggest there is sufficient theoretical and empirical justification to warrant further exploration into mentorship's impact on protégé leader development. Our main purpose here was to examine how a formal mentorship program that torgeted improving protégés' leader development would perform when it was compared against a more traditional leadership education program delivered in a group setting. Beyond assessing the overall impact of mentorship on leader development, we also sought to identify key factors that may accelerate the level of growth protégés experience. Toward that end, the literature suggests that both mentor-protégé relational factors and protégé individual difference factors may play pivotal roles in the success of mentorship (Krom, 1985; Phillips-Jones, 1982). With this in mind, we selected a relational factor-trust-and an individual difference factor-feedback-seeking preference-to test their influence on development across both conditions. We selected these factors, based on the literature, because they are thought to represent how "ready" the relationship is to exchange honest developmental feedback between parties-and how "ready" the individual is to receive and process honest feedback-both of which are critical in mentoring (Kram, 1985; PhillipsJones, 1982). Understanding such factors may help leader developers design more effective mentorship programs as well as select participants. If mentorship is shown to be effective, organizations would have greater justification for developing leaders through in-house mentoring programs, where "the mentor provides support, direction, and feedback regarding career plans and personal development to the more junior protégé" (Russell \& Adams, 1997: 2).

There are at least three significant benefits to testing the efficacy of a mentorship program focused on enhancing leader development. First, mentorship programs are likely to be more cost effective than traditional group-based interventions because they do not require contracted trainers, expensive keynote speakers, special classrooms, conference facilities, or other logistical resources. Second, because the mentorship program focuses on leader development, many mentors will also improve as leaders and leader developers alongside their protégés, and will, thus, likely be better prepared to lead their own organizations. Third, applying the knowledge gained through mentorship will likely be easier than applying knowledge gained through group interventions because the actual work context is the focus. Thus little is "lost in translation" because the mentor and protégé are inherently familiar with the problems, issues, and examples used during the mentoring sessions as opposed to training courses delivered by outside instructors.

\section{Building on Prior Empirical Research on Leader Development}

Prior evidence demonstrates that the effectiveness of either leader or manager development initiatives varies widely across the nature of the intervention (e.g., length, focus, support, follow-up, etc.), and the theoretical framework supporting the in- 
tervention (Avolio et al., 2009; Burke \& Day, 1986). Current research also suggests that the financial return on investment associated with different developmental initiatives varies widely across types of leader development interventions, depending on such things as the length of the intervention, the target trainee's characteristics, level of organizational support, the leadership framework supporting the training intervention, and of course, the cost of the program (Avolio, Avey, \& Quisenberry, 2010).

Narrowing our focus on the trainee, recent research examining the heritability of leadership has shown that nearly two thirds of the variance in leader emergence across the career spans of identical versus fraternal twins was attributable to experience and other environmental factors, while only one third was due to heritability (Avolio, Rotundo, \& Walumbwa, 2009). Here, the type of life events and experiences typically associated with leader development interventions (e.g., role modeling or mentoring) were identified as significant contributors to leader emergence and performance. Timing of the intervention also matters; these researchers found that early life events were more impactful than events later in life. According to Avolio (2011) and Lord and Hall (2005), early intervention is critical insofar as it impacts the trainee's implicit leadership theories and his or her leader self-concept, a basic building block for developing, organizing, and implementing what are later exhibited as one's leadership skills. Consequently, to the extent that viewing oneself as a leader is part of one's early identity, the cognitive self-structure that is created becomes a framework for codifying experiences from leader development interventions that can benefit subsequent leader development (Hannah, Woolfolk, \& Lord, 2009; Lord \& Hall, 2005). This focus is in contrast to the more general and less individualized group training efforts that would not as closely target the leader's self-concept, and we suspect, would have a less positive impact on leader development. When taken together, we therefore suggest that a mentorship program focused on developing aspects of a protégé's leader identity would be a critically important step, particularly during the early stages of leader development, which characterizes the sample in the present study.

\section{Role of Leader Self-Efficacy in Leader Development}

According to van Knippenberg, van Knippenberg, De Cremer, and Hogg (2004), one aspect of leader identity thought to be most relevant to enhancing leader development and performance is the leader's self-efficacy (cf. Bandura, 1997; Hannah \& Luthans, 2008). In their review of the leader efficacy literature, Hannah, Avolio, Luthans, and Harms (2008: 2) defined leader efficacy as "[l]eaders' (followers') beliefs in their perceived capabilities to organize the positive psychological capabilities, motivation, means, collective resources, and courses of action required to attain effective, sustainable performance across their various leadership roles, demands, and contexts." We suggest that leader efficacy is a critical component in leader development, and moreover an aspect of leadership that con be effectively developed in the mentor-protégé relationship. Consequently, building on the above literature, we focus here on extending mentorship theory and research by developing and testing a model linking mentorship to protégés' development of leader efficacy.

Leader efficacy is an important leader attribute that has been linked to ratings of leader and manager effectiveness or performance (Chemers, Watson, \& May, 2000; Luthans \& Peterson, 2002; Prussia, Anderson, \& Manz, 1998; Robertson \& Sadri, 1993); attempts to lead (McCormick, Tanguma, \& LopexForment, 2002; Paglis \& Green, 2002); leader strategy use (Kane, Zaccaro, Tremble, \& Masuda, 2002); and organizational performance (Wood \& Bandura, 1989). Generally speaking, one's efficacy is important not only in driving leader effectiveness, but also because it influences choices of which experiences and challenges to pursue, and thereby, opportunities for future leader development (Bandura, 1997), which Day and Harrison (2007) propose can create positive development spirals. Day and Harrison also emphasize that these spirals are very idiosyncratic, and therefore, focusing on nurturing each target leader's development would be considered a more effective strategy for leader development. Mentoring programs are frequently described as being highly customized to the protégés' needs (Johnson, 2007), and thus, should be ideally suited for fostering unique developmental trajectories of leaders.

Based on our review of the literature, we have not found any studies assessing the link between mentorship and leader efficacy. However, two correlation studies have assessed the effects of mentoring on other forms of efficacy. Day and Allen (2004) reported that mentoring was related to government employees' self-efficacy for managing their own careers. Paglis, Green, and Bauer (2006) reported that faculty mentoring was marginally related to doctoral students' self-efficacy for conducting research. The current study, thus, in part answers Ramaswami and Dreher's (2007) call for 
further research into examining the relationship between mentorship and efficacy. Specifically, we seek to extend the literature by examining how mentorship develops leader efficacy in protégés.

We also attempt to address calls for research to assess the mechanisms whereby mentoring (e.g., Day \& Allen, 2004) and leader development more broadly (Avolio, 2007; Avolio, Walumbwa, \& Weber, 2009) result in observable outcomes. Toward this end, we assessed whether leader efficacy mediates the relationship between enhanced mentorship effects and externally rated leader performance. Briefly, our model follows Day's (2000: 584) dichotomy of leader and leadership development, where leader development "results as a function of purposeful investment in human capital. . . [and where] the primary emphasis of the overarching development strategy is to build the intrapersonal competence needed to form an accurate model of oneself." We set out to collect longitudinal evidence to determine whether mentorship can be an effective leader development intervention that enhances leader performance through fostering protégés' leader efficacy.

Consistent with the theoretical frameworks offered by Day and Harrison (2007), DeRue and Ashford (2010), Hannah and colleagues (2008), and van Knippenberg and colleagues (2004), we explore self-efficacy as one aspect of leaders' selfconstrual of their capabilities to lead, and we suggest that mentorship serves as a pathway to elucidate that construal. We propose that this pathway is socially constructed in part as the mentor encourages the protégé to attempt leadership acts and subsequently recognizes and validates those acts, in turn validating the protégé's identity as a leader (DeRue \& Ashford, 2010). We propose this mentorship-efficacy pathway is further strengthened when the trust bond between the mentor and protégé is strong, and that it is further reinforced when the protégé is open and willing to seek critical and tough feedback from the mentor. A model depicting the constructs in this study and their proposed relationships is shown in Figure 1.

We tested this model in a true field experiment with participants randomly assigned to either a tailored and structured mentorship program or to a comparison group that would participate in a group leadership training program conducted in a classroom setting over the same 6-month period. Below, we provide a summary and integration of the literature on mentorship and leadership development that provided the basis for formulating the research questions and hypotheses examined here. Next, we outline details regarding the field study and cover the analyses and results. We later discuss the findings and conclude with the study's limitations and implications.

\section{MENTORING AND THE DEVELOPMENT OF LEADER EFFICACY}

Hannah and colleagues (2008) drew from various areas of efficacy research (educational, clinical,

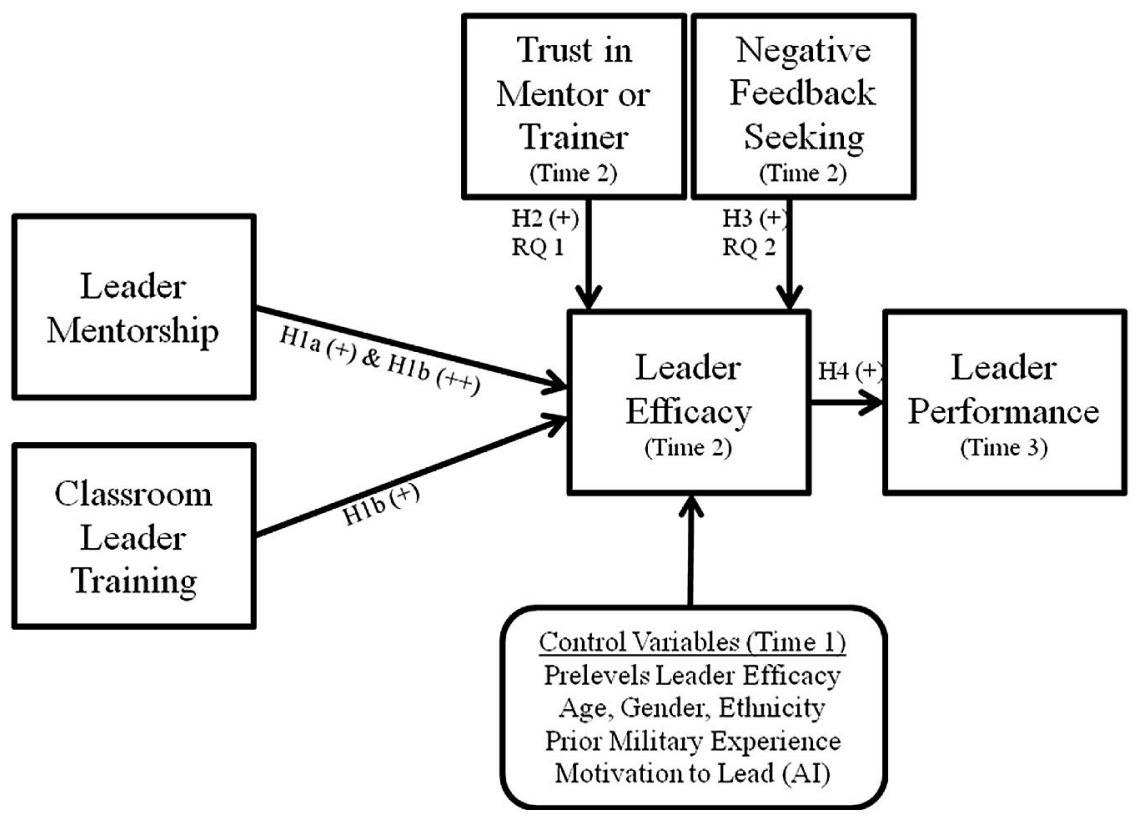

FIGURE 1

Framework for Mentorship in Leader Efficacy Development 
cognitive and social psychology, organizational behavior, and leadership) to develop a theoretical model specifying that there are three general selfefficacy components of leader efficacy. First, they suggest that leaders require efficacy to perform various leadership tasks (i.e., leader efficacy for action), which has been the primary focus of prior research on leader efficacy. They submit that leaders also require efficacy in terms of their perceived capability to effectively interpret a leadership challenge and then generate novel leadership solutions to that challenge (i.e., leader efficacy for thought). Also, given the demands and challenges inherent in leading, leaders must see themselves as being capable enough to produce sufficient motivation to act (i.e., leader efficacy for selfmotivation). In line with the theorizing of Gist and Mitchell (1992), we suggest that leaders call on or "orchestrate" the three domains of action, thought, and self-motivation when formulating leader efficacy.

Our review of the efficacy literature failed to uncover any published studies assessing the development of leader efficacy over time. Limited studies have identified correlates of leader efficacy. For example, Mellor, Barclay, Bulger, and Kath (2006) found in a correlation study that junior union leaders' efficacy to serve as union stewards was positively associated with encouragement by their leaders. Despite the lack of empirical research specifically focusing on leader efficacy development, there is ample evidence to support the development of self-efficacy in general, including the four proven techniques of using mastery experiences, vicarious learning, social persuasion, and arousal (Bandura, 1997). Similar to our approach, Day and Allen (2004) and Paglis and colleagues (2006) used these four techniques as the basis to establish theoretical links between mentoring and protégé self-efficacy in areas outside of leader efficacy.

\section{Mastery Experience}

In his review of numerous intervention studies, Bandura (1997) stated that the most potent antecedent to developing self-efficacy is mastery experiences based on past performance accomplishments. However, Bandura (1997) also made clear that prior success alone does not raise selfefficacy; development is influenced by how the individual interprets the success and the context that performance occurred in. This suggests mentoring that helps leaders make meaning of their prior leadership experiences could be important in influencing development. We suggest that this is a primary role of mentors.

DeRue and Ashford (2010) suggested that leaders' identity construction occurs through social interaction, through claiming and granting of leadership. Individuals "claim" leadership through stepping up and attempting to influence others. Others then "grant" leadership through affirming and supporting that leader's attempts. Through this reciprocal process, individuals begin to see themselves as capable leaders, reinforcing a leader identity. We suggest that mentors can serve similar functions, and as experienced role models, can be powerful sources to provide such external endorsement. A primary role of mentors is to provide psychosocial support to protégés, helping them to diagnose their prior actions, cast those actions in a positive light, and to serve as a source of validation for the protégé (Kram, 1985). DeRue and Ashford (2010) proposed that solidification of a leader identity ultimately requires endorsement from others, including one's mentor, peers, or followers. Further, as mentors increase protégés' sense of competence, self-esteem, and efficacy, we would expect a spiral effect to occur as noted earlier. Specifically, we would expect protégés to feel more encouraged and safe to explore their leadership than those without a mentor, and thus, increase attempts to claim leadership in their groups, thereby increasing leadership claimgrant episodes. Finally, when mentors are senior leaders in the organization, such as in the current field study, we would expect that due to their status their endorsements may serve as a proxy representing the collective endorsement.

\section{Vicarious Learning}

Leader efficacy can also be developed through modeling or vicarious learning, where individuals observe competent and relevant role models successfully performing similar tasks, or cognitively model leadership experiences through envisioning successful performance. The impact that modeling or vicarious observations hold is based on how attractive the role model is to the observer, the level of similarity between the model and the observer on characteristics that are relevant to the task, and how similar the observed task is to those tasks the observer may perform (Bandura, 1997; Stajkovic \& Luthans, 1998). It is important to note that in their meta-analysis of manager training studies, Burke and Day (1986) demonstrated that behavioral modeling was in general the most effective form of intervention as compared to sensitivity training, lecture, or other techniques. 
In line with Scandura (1998) and Payne and Huffman (2005), we suggest that mentorship relationships work in part because of the role modeling exhibited by the mentor to the protégé, as this influences development of leader efficacy beliefs by the protégé, which we explore next. Mentors serve many purposes, but they primarily act as role models who walk protégés through prior or future leadership actions, helping them to cognitively model and learn aspects of successful performance (Kram, 1985; Phillips-Jones, 1982). Related to role modeling, we expect that when protégés are allowed to select their own mentors, as done here, they will find more substantial role-modeling effects and resulting efficacy change.

Information-processing approaches to leadership hold that followers develop schemas of prototypical leadership qualities based on attractive leaders they observe (Lord, Foti, \& DeVader, 1984). These attractive role models serve as the prototype upon which observers then identify and base their future development (Ibarra, 1999). The role model becomes the observers' "possible self," and they begin to believe that they too can develop toward and achieve performance similar to their role model (Lord \& Brown, 2004). We expect that a chosen mentor would potentially represent that prototypical leader for the protégé, thus fostering their leader efficacy development.

\section{Social Persuasion}

The third source of efficacy development noted by Bandura (1997) is social persuasion, which constitutes a primary role inherent in mentoring (Kram, 1985; Phillips-Jones, 1982). Even when feedback is negative (e.g., discussing on incident of poor performance), leaders can provide feedback in a positive manner, highlighting what was learned and how feedback can then be used to enhance future performance (Berson, Shamir, Avolio, \& Popper, 2001; Garland \& Adkinson, 1987). What is critical is that the mentor instills in the individual the importance of growing and developing from all sorts of feedback, which we would expect to influence the protégé's efficacy regarding his or her leadership (Dutton \& Dukerich, 1991). In part supporting this claim, Mellor and colleagues (2006) demonstrated that encouragement and persuasion from senior leaders was associated with junior leaders' efficacy to take on leadership roles. This approach is also in line with evidence showing how individualized consideration associated with transformational leadership positively relates to leader and follower development/performance (Bass \& Bass, 2008).

\section{Arousal}

The fourth primary way to develop self-efficacy is psychological, physiological, and emotional arousal (Bandura, 1997). Here, mentors could serve in the role of inspiring and otherwise "firing up" protégés to motivate their development. Such arousal can be generated through inspirational motivation or creating an idealized vision for the protégé (e.g., Avolio \& Luthans, 2006; Berson et al., 2001), or through sources of emotional contagion (e.g., Bono \& Ilies, 2006), whereby mentors' excitement transfers to protégés and spurs them to further develop leader efficacy.

In sum, organized mentorship programs have been effective in developing various positive outcomes in protégés (e.g., Payne \& Huffman, 2005; Ortiz-Walters, 2009; Allen \& Eby, 2003). We suggest that a mentorship program targeting the four primary sources of efficacy discussed above would be particularly effective in raising protégés' leader efficacy and performance. Indeed, we suggest that these four sources of efficacy are inherent in the role of any effective mentor and mentoring relationship.

\section{Mentoring Versus Group Interventions}

We propose that mentoring will increase protégés' leader efficacy more so than traditional groupbased training focused on leadership development. Based on the research and theory reviewed above, we suggest that by developing a more individualized relationship between the mentor and protégé, the promotion of positive trajectories of leader development will be enhanced. To the degree that the mentor can connect to the individual protégé's needs, abilities, and aspirations, a mentoring program will have a more positive impact on leader efficacy development and performance than a more generalized, ready-made leader training intervention.

Prior research has indeed shown that more individualized leadership development, in which individualized coaching was used to boost leader development effects, was related to follower selfefficacy (Dvir, Eden, Avolio, \& Shamir, 2002; Kark, Shamir, \& Chen, 2003), and we expect the same effect would result between mentors and protégés working on leader development. An individualized focus helps torget protégés' specific needs and capabilities, enhancing efficacy development (Bandura, 1997; van Knippenberg et al., 2004). Such supportive leadership has also been linked to higher levels of follower self-efficacy (Choi, Price, \& Vinokur, 2003). It seems reasonable to expect that 
one-on-one mentoring, on average, will provide more consistent opportunities for the mentor to employ the four methods of developing self-efficacy and adjust the leader development intervention to the exact needs of the protégé, thus enhancing protégé efficacy and performance. Based on this literature, we offer our first set of hypotheses:

Hypothesis la: Participation in a leadership mentorship intervention using mastery experiences, vicarious learning, social persuasion, and arousal will lead to an increase in leader efficacy.

Hypothesis 1b: Participation in a leadership mentorship intervention will increase levels of leader efficacy to a greater extent than participation in group classroom leader development intervention.

\section{TRUST, FEEDBACK-SEEKING ORIENTATION, AND PERFORMANCE}

The mentorship literature suggests that individual differences across protégés as well as relational factors related to the protégé-mentor relationship serve to influence the success of mentorship programs. Similarly, theory on what constitutes leader developmental readiness (e.g., Avolio \& Hannah, 2008; Hannah \& Avolio, 2010) emphasizes that to grow, leaders must be motivated and open to discover their strengths as well as their weaknesses, and they must be embedded in a context that supports openness, exploration, and growth. To represent these two aspects, we selected two foundational variables-feedback-seeking orientation and trust, respectively. Below we outline how feedback-seeking orientation is foundational to one's view of the self and influences the manner with which developmental feedback is attended to and interpreted (e.g., DeRue \& Wellman, 2009). Further, it is well established that trust serves as a foundation of most high-functioning relationships, such as what could be expected to be seen in a candid and effective mentor-protégé relationship (Cropanzano \& Mitchell, 2005; Mayer, Davis, \& Schoorman, 1995). While these two factors have been cited as critical to successful mentorship relationships (e.g., Krom, 1985; Phillips-Jones, 1982), to our knowledge, neither has been tested in an experimental setting. Throughout the discussion below, we describe how trust and feedback-seeking orientation can influence the development of protégés' leader efficacy, and we later describe the relationship between protégés' leader efficacy and performance.

\section{Mentor-Protégé Trust}

One of the key factors that impacts the success or failure of mentorship programs is the presence of trust between the mentor and protégé (Richard, Ismail, Bhuian, \& Taylor, 2009). Mayer and colleagues (1995: 712) defined trust as "the willingness of a party to be vulnerable to the actions of another party based on the expectation that the other will perform a particular action important to the truster, irrespective of the ability to monitor or control that other party." In a mentor-protégé relationship, allowing for vulnerability requires that the truster (protégé) feels able to disclose personal information and openly expose shortcomings and weaknesses as a leader, while feeling confident that the mentor has his or her best interests in mind and will be discreet with that information. Trust is thus necessary for the creation of psychological contracts that one would expect in an effective mentor-protégé relationship (Cropanzano \& Mitchell, 2005; Robinson \& Morrision, 2000). Richard and colleagues (2009) demonstrated, for example, that when higher levels of trust existed between protégés and their mentors, protégés had higher levels of organizational commitment and lower intentions to quit. Further, Dymock (1999) demonstrated that trust in mentoring relationships fostered greater transfer of knowledge between the two parties, which is important if the mentor is to provide developmental advice and feedback to shape the protégé's development.

One additional reason to expect trust to be associated with development is the close association between trust and adult attachment styles (Harms, in press). In attachment theory (Bowlby, 1982), the view is that all individuals have a deep-seated desire to form close, secure bonds with attachment figures (e.g., parent, mentor, leader, etc.) in their lives. When these bonds are formed, individuals with a secure attachment feel freer to explore their environment, try new things, and engage in activities that they would otherwise not attempt (Fraley \& Shaver, 2008). Mikulincer and Nachshon (1991) have demonstrated that individuals with a secure attachment style are more willing to open themselves up and disclose personal information to others. Consequently, when protégés are able to form these trusting relationships with attachment figures, such as their mentors, we expect that they will be more responsive to feedback and more willing to engage in activities that may benefit their development.

Mayer and colleagues (1995) suggested that there are three factors that make someone trustworthy. First, they must demonstrate that they 
have the ability to fulfill their part of the bargain. Related to mentoring, this may take the form of giving sound counsel and having the interpersonal skills necessary to be an effective mentor, as well as possessing the leadership skills that justify the mentor as a worthy exemplar for the protégé. Second, a trustworthy person demonstrates benevolence, which as alluded to previously, includes an inclination to hold the protégé's best interests in mind. Third, trustworthiness requires that the truster perceives that the trustee has high levels of personal integrity. When these factors are present and protégés establish higher levels of trust in their mentors, we expect the effects of mentorship on leader efficacy development will be enhanced. As noted earlier, this is because leader efficacy development requires change to the deep structure of a leader's identity, which is best facilitated through deep self-reflection and meaning-making (Lord \& Hall, 2005; Lord, Hannah, \& Jennings, 2011). For this to occur in a mentoring relationship, the protégé must feel comfortable openly exploring who they are and how they can become a more effective leader-and such a level of interpersonal dialogue and social exchange requires high levels of trust (Cropanzano \& Mitchell, 2005; Mayer et al., 1995). Trust is especially important in the current military field context, where individuals who are fairly demographically similar operate in a relatively strong culture centered on shared values and shared identity, as well as high levels of interdependence between leaders and followers to achieve mission accomplishment in challenging conditions-all which may sponsor the formation of trust (Hannah, Campbell, \& Matthews, 2010). This leads to our second hypothesis:

Hypothesis 2: Leaders who have higher levels of trust in their mentor will experience higher levels of leader efficacy development.

Further, we sought to explore how trust operates across our two experimental conditions in terms of impacting leader efficacy development. We specifically assessed whether the effect of trust in one's mentor on leader efficacy development was greater in a mentorship intervention as compared to a more eclectic noncustomized group leadership training program conducted in a classroom setting. Thus we examined the following research question:

Research Question 1: Does the effect of trust in one's mentor on levels of leader efficacy development in a mentorship program differ from the effects of trust in one's leader on levels of leader efficacy development in a group classroom leader development intervention?

\section{Feedback-Seeking Orientation}

Besides the relational factor of trust, we also sought to determine how individual differences across protégés based on feedback-seeking orientation may influence the development of leader efficacy. DeRue and Ashford (2010) highlighted that personal agency is a critical component in leader development and that leaders must engage themselves into seeking and processing information about their leadership to accelerate their development. For example, protégés who assume a greater amount of input into the mentoring process have shown greater commitment and job satisfaction (Allen, Eby, \& Lentz, 2006). DeRue and Ashford proposed that the self-directed ways leaders approach and frame leader development experiences, the actions they take toward their development, and the reflection they conduct on those experiences all influence leader development. This parallels the work on leader developmental readiness (Avolio \& Hannah, 2008; Hannah \& Avolio, 2010), which suggests that leaders vary in the extent they are oriented toward their own development as well as in the extent they are able and motivated to explore both their strengths and weaknesses without defensiveness.

One critical factor related to developmental readiness that has been proposed in the literature is leaders' orientation toward receiving positive and negative feedback (DeRue \& Wellman, 2009). Individuals possess varying preferences for positive or negative feedback (Ashford, Blatt, \& VandeWalle, 2003; Ashford \& Tsui, 1991; VandeWalle, 2003). These preferences are thought to be driven by personality factors and orientations that influence self-regulation, such as goal orientation and self-enhancement motives (Ashford et al., 2003; DeRue \& Wellman, 2009). Individuals' preference for positive or negative feedback are important determinants of various cognitive, affective, and behavioral reactions with which they react to feedback, and therefore, influence the potential impact feedback has on their development (Ilgen, Fisher, \& Taylor, 1979). We suggest that protégés who engage themselves in the mentoring process and are more willing to openly consider negative feedback will process a greater expanse of developmental input, facilitating development of leader efficacy over time.

Dweck (1989) noted that individuals tend to take on one of two perspectives regarding development: 
they toke on "entity" perspective (belief that they cannot change), or they take the "incremental" perspective (belief that they can change over time). Those with an incremental perspective tend to have a learning orientation where they seek out new experiences and feedback to enhance their development, and thus, are more prone toward self-verifying motives. Those with an entity perspective, however, feel they cannot change, and thus, view experiences as tests of their capabilities versus as learning opportunities. These individuals are more prone to seek self-enhancement feedback. Entity and incremental approaches are linked to performance goal orientation and learning goal orientation, respectively (Button, Matieu, \& Zajac, 1996), and these orientations then manifest in corresponding preferences for positive (e.g., selfenhancing) or negative (e.g., self-verifying) feedback (Ashford \& Cummings, 1983; Crant, 2000; Lam, Huang, \& Snape, 2007).

Leaders who actively seek out negative feedback are less likely to seek impression management through controlling the feedback messages received or attended to and tend not to crave feedback that is self-enhancing or overly positive (Lam et al., 2007). Stated another way, learning-oriented leaders tend to seek the unvarnished truth to improve. While not focused specifically on leader development, a longitudinal study of students showed that students' level of incremental (as opposed to entity) approach to change was positively associated with levels of development (Robins, Noftle, Trzesniewski, \& Roberts, 2005). We expect that leader efficacy will be enhanced when the leader is willing to face and address his or her weaknesses, suggesting higher levels of developmental readiness (Avolio \& Hannah, 2008; Hannah \& Avolio, 2010).

Indeed, Hannah and colleagues (2008) suggested that leader efficacy development will be enhanced when leaders practice adaptive self-reflection, defined as a constructive process of reflection consisting of patterns of thinking and emotions that are open, positive, and learning oriented (Trapnell \& Campbell, 1999). According the Hannah and colleagues (2008), such open reflection is required to achieve the level of deep self-concept change required to develop lasting increases in leader efficacy. Indeed, openness to explore aspects of the self can result in greater self-awareness that contributes to effective self-regulation over time (Carver \& Scheier, 1982). In contrast, maladaptive self-reflection involves self-deceiving or destructive ways of thinking that generates negative emotions such as anxiety, self-doubt, and fear
(Mor \& Winquist, 2002), all of which can diminish development.

Ashford and colleagues (2003) provided an overview of research showing that when feedback is contingent (i.e., feedback is in a domain for which the person defines themselves and bases their self-worth), that ego-defense mechanisms will be especially powerful. This suggests that if being a leader is central to one's self-concept (Hannah et al., 2009), and the person is also closed to negative feedback, this may limit the amount of accurate developmental feedback they consider, thus limiting their growth. Ashford and Tsui (1991) proposed that this type of limiting process occurs in part based on control theory (Carver \& Scheier, 1982), because when people limit negative feedback, they fail to see how far they may be from standards. Yet, it is realizing those discrepancies between the actual and ideal self that drives the self-regulation to develop as a leader (Lord \& Brown, 2004). Based on this discussion, we expect that protégés' orientation toward positive feedback would validate their actual (i.e., current) self, deterring development, while orientation for negative feedback will be an important factor in their use of contingent feedback to enhance their development. This leads to our next hypothesis:

Hypothesis 3: Protégés' level of orientation for negative feedback will be positively related to their level of development of leader efficacy when participating in a mentorship program.

Further, as with trust, we sought to assess whether the effects of feedback-seeking orientation varied when participating in mentorship as compared to group classroom leader development. This leads to our next research question:

Research Question 2: Does the effect of protégés' orientation for negative feedback on levels of leader efficacy development in a mentorship program differ from that in a group classroom leader development intervention?

\section{Leader Efficacy and Leader Performance}

Bandura and Locke (2003: 87) noted that "[efficacy beliefs] affect whether individuals think in selfenhancing or self-debilitating ways, how well they motivate themselves and persevere in the face of difficulties, the quality of their well-being and their vulnerability to stress and depression, and the choices they make at important decision points." These effects of self-efficacy drive human 
performance, and meta-analyses have demonstrated significant relationships between selfefficacy and various work outcomes to include performance (e.g., Stajkovic \& Luthans, 1998).

Specific to leader efficacy, scholars have noted in literature reviews that confidence is a critical leader attribute (House \& Aditya, 1997; Yukl \& Van Fleet, 1992). Leader efficacy is proposed to provide psychological resources that drive more effective leader engagement, flexibility and adaptability across varying challenges and situations (Conway, 2000; Hannah \& Luthans, 2008). This is because leaders must determine that they have sufficient capability to achieve success before they will engage their full cognitive and physical efforts in a given task.

The limited body of empirical research has linked leader efficacy to various important outcomes (see review by Hannah et al., 2008). Examples include ratings of leader potential (Chan \& Drasgow, 2001); attempts to take on leadership positions (McCormick et al., 2002; Paglis \& Green, 2002); motivation to lead (Chan \& Drasgow, 2001); simulated organizational performance (Wood \& Bandura, 1989); and manager performance ratings (e.g., Chemers et al., 2000; Robertson \& Sadri, 1993). Therefore, we present our final hypothesis:

Hypothesis 4: Leaders' level of leader efficacy will be positively related to their leader performance ratings.

\section{METHODS}

\section{Description of Program}

To test Hypotheses 1-4, the authors served as subject matter experts for the United States Military Academy (West Point) to design and implement a pilot mentorship program to be tested for potential implementation across the institution. Specifically, we sought to determine if a new one-on-one formal mentorship program (treatment group) would be more effective at developing leader efficacy than the organization's current program, a more generalized leadership training program conducted in group settings (comparison group). The study began with collection of demographic and control variables and prelevels of leader efficacy (Time 1), with subsequent intervention occurring over a 6month period, ending with Time 2 data collection of trust, feedback-seeking orientation, and postlevels of leader efficacy. Performance ratings were then collected 3-4 weeks after Time 2 on each cadet (Time 3).

Many studies have examined mentorship relationships retrospectively using survey methodol- ogy (e.g., Allen \& Eby, 2003; Finkelstein, Allen, \& Rhoton, 2003; Kay, Hagan, \& Parker, 2009; Payne \& Huffman, 2005; Richard et al., 2009). To increase our causal interpretability, we used a more rigorous experimental design for this longitudinal field study. Four hundred ninety-nine cadets were identified by the organization to participate as protégés. These cadets were in their 4 th (senior) year at the Academy, and all were serving in leadership positions where they supervised the three classes of cadets below them. These cadet protégés were randomly assigned to either the treatment or comparison group.

While involvement in the pilot mentorship program was mandatory for these 499 cadets, their participation in the study was voluntary and subject to informed consent. Of the 499, 376 cadets provided data at Time l. Two hundred thirty-six of these cadets $(63 \%)$ also volunteered to provide data at Time 2. Of these, a small number were removed from further data analyses because their responses indicated that they were not taking the surveys seriously. To be conservative, we removed 13 participants as outliers, as their scores on the leadership efficacy increased by more than two standard deviations. Further, 30 participants were removed because their responses were invariant across multiple scales in the survey (e.g., responding with only four on a 5-point scale). ${ }^{1}$ Because of these screens, 193 cadets provided useable data, including 76 from the treatment condition and 117 from the comparison condition. The average age of participants was 21.7 years, $81.35 \%$ were Caucasian, $80.0 \%$ were male, and $95.0 \%$ had no record of prior military service.

\section{Common Experiences Across Both Conditions}

Unlike most civilian educational institutions, the West Point experience is by design on intense 47month leader development intervention (United States Military Academy, 2009). The West Point experience is a structured and immersive, 24 hours a day, 7 days a week program resulting in the commissioning of Army lieutenants. All cadets are required to serve as leaders within a military chainof-command, act as tactical unit leaders during

\footnotetext{
${ }^{1}$ We conducted tests to establish whether there were significant differences between the set of cadets who were removed from further analysis for either completing the second set of assessments using invariant response patterns or extreme responses. We ran a series of $t$ tests comparing the initial leader efficacy and motivation to lead scores, as well as all available demographic variables. No significant differences were found for any of the variables tested between these two groups.
} 
military training, participate mandatorily as either collegiate or intramural athletes, and perform as college students in the classroom. Adding to the experience, all cadets are closely monitored and graded on their performance in each of these domains.

In the leadership domain, all cadets rotate through a series of progressive formal leadership positions during their 4 years at West Point, culminating in their senior year (the current sample) as officers appointed over all three lower classes of cadets. Beyond typical leader-follower feedback garnered through day-to-day interactions, cadets receive structured feedback with monthly counseling sessions with their direct leader and also triannually by way of a robust multirater assessment tool. Last, cadets also receive formal feedback from active duty Army officers serving as tactical officers with oversight over their daily development. Note that all cadets from both conditions were immersed in this intense 4-year leader development experience and that the additional interventions conducted as part of the treatment and comparison conditions in this study served as only one incremental addition to a larger development regime.

\section{Treatment Group Intervention}

In addition to the rich leader development experiences noted above, cadets in the treatment condition participated in a formal mentorship program over a 6-month period. According to Johnson and Andersen (2010: 116), formal mentorship "is instigated by an organization and usually involves formal assignment or matching of mentee [protégé] with mentor." Here, the institutional leadership chose a semiformal approach for its mentorship program where participation was mandatory, but protégés were free to select mentors of their choosing from the staff and faculty of the military academy. The semiformal program required at least six meetings between the mentor and protégé across one academic semester, although they could meet more often if they desired. The mentors were provided with the following set of general goals for each of the six mentoring sessions, but the program did allow for some topic flexibility:

- Session 1: Established the basis of the mentor-protégé relationship (roles and expectations) and establish developmental goals for the protégé. Protégés were required to write and share with their mentor a 2-3 page essay on what they understood mentorship to be about and what they hoped to gain from the experience.
- Session 2: Focused on helping the protégé diagnose and learn from prior leadership challenges where they were in ambiguous situations with conflicting priorities and values. Discussion centered on how to take charge as a leader and properly resolve similar problems in the future. Protégés provided the mentor $a$ 2-3 page essay about these prior leadership situations in advance of the meeting.

- Session 3: Focused on the protégé's personal developmental goals. Here, the mentor discussed methods and opportunities for protégés to reach those goals and explained his or her own developmental experiences. Protégés had a writing requirement similar to those in previous sessions.

- Session 4: Focused on how to effectively assess and lead during tough ethically or morally ambiguous situations and how properly doing so impacts subordinate soldiers. Protégés had a writing requirement similar to previous sessions.

- Sessions 5 \& 6: Select a topic-these sessions were open for mentor-protégé pairs to select topics of choice, but they were instructed to keep their discussions within the realm of protégé leader development topics. The writing requirement continued as per previous sessions.

In addition to these six sessions, protégés were each required to conduct two interviews with military officers whom they considered role models, and these role models had to be officers other than their mentors or their unit tactical officers. The purpose of these interviews was to provide each protégé with another expert source of feedback. Last, protégés wrote a final essay about their mentorship experience and discussed it with their mentors, also outlining what they hoped to incorporate into future mentorship relationships.

\section{Comparison Group Intervention}

Parallel to the mentorship condition, cadets in the comparison group attended six classroom sessions (student/teacher ratio-approximately 16:1) where similar leadership and character-based leader development topics were discussed, along with eclectic discussions about leadership styles and techniques. In addition, the essay and journaling topics for the comparison group differed from the protégé group, where instead of writing about their mentoring, they were instructed to write essays on leader character. Further, cadets in the comparison group neither met with mentors, nor did they conduct the role-model interviews or write the final essay on mentorship. 


\section{Measures}

\section{Feedback Orientation}

We collected feedback orientation at Time 2 using the scale developed by Ashford and Tsui (1991). This scale consisted of three items measuring a desire for tough/negative feedback and three items measuring a preference for easy/positive feedback. This measure uses a 5-point response scale $(1=$ Almost never; $5=$ Almost always $)$ indicating how often participants' engaged in specific feedback-seeking orientation. The negative items $(\alpha=.81)$ were "ask him/her to be critical when giving you feedback," "prefer detailed, frank feedback, even when they might hurt," and "really want honest feedback." The positive items ( $\alpha=.75)$ were "tend to seek good news about yourself," "ask for feedback when you expect that it would be positive rather than negative," and "prefer positive rather than negative feedback."

\section{Trust}

Trust was assessed at Time 2, using a version of the Mayer and Davis (1995) trust scale modified to target the mentorship relationship. This scale consisted of nine items. Cadets in the treatment condition were instructed to rate the extent to which they trusted their mentor. Cadets in the comparison condition were instructed to rate their tactical officer (which, as previously outlined, is the leader held responsible for that cadet's development). Example items (worded to rate a mentor) include "I would be comfortable depending on my mentor's word," "If I had my way, I wouldn't let my mentor have any influence over issues that are important to me" (reversed), and "If someone questioned my mentor's motives, I would give them the benefit of the doubt." Participants responded to items using a 6-point response scale ( $1=$ strongly disagree; $6=$ strongly agree; $\alpha=.88)$.

\section{Leadership Efficacy}

Leadership efficacy was assessed at both Times 1 and 2, using Hannah, Avolio, and Walumbwa's (2008) 15-item leader self-efficacy measure $(\alpha=.96)$. This measure is based on the model proposed in the leader efficacy literature review of Hannah and colleagues (2008) and focuses on both self-regulatory (thought and self-motivation) and action aspects of leader self-efficacy. Example self-regulatory items include "As a Leader I Can. . think up innovative solutions to challenging problems," "determine what leadership style is needed in each situation," and "motivate myself to take charge of a group," as well as a component reflecting leaders' efficacy to act including example items: "coach followers to assume greater responsibilities for leadership," "get followers to identify with the central focus of our mission," and "energize my followers to achieve their best." Using a standard approach recommended by Bandura (1997), participants indicated their confidence in their ability related to each item on a scale of $0-100$ $(0=$ not confident at all; $100=$ totally confident $)$. This leader efficacy measure has been tested across six samples to confirm its psychometric properties and construct validity, to include a military sample in which leader efficacy predicted performance ratings. Hannah et al. (2008a) reported across samples that these 15 items represent $a$ general factor representing leaders' overall level of leader efficacy, which is how we scored this measure in the current field study.

\section{Performance}

During the entire 6 months of the study, each cadet's performance was closely observed and externally rated by their tactical officer using the institution's standard performance rating system. This rating was issued at Time 3, 3-4 weeks after Time 2 data were collected. According to organizational procedures, the tactical officer assigns each cadet an overall combined rating in the form of a letter grade based on three factors: the summation of their scores on various objective performance events during the rating period (e.g., military tactics scores); personal subjective observations of each cadet's overall performance during leadership tasks; and input on each cadet's leadership performance received from other training cadre and more senior cadets in the chain-of-command. The tactical officer uses these three inputs to assign each target cadet an overall performance grade ranging from $F$ to $A+$, which we transformed into an interval scale of $1-10(M=7.36, S D=1.89)$. The tactical officers assigning these grades did not concurrently serve as mentors to the cadets.

\section{Control Variables}

To limit alternative explanations for our findings and add rigor to our analyses, we controlled for six variables. These included pretest levels of leader efficacy, age, gender, and ethnicity. As some cadets may have served in the Army prior to attending West Point, which could enhance their leader efficacy and military leadership performance, we also controlled for prior military experience $(1=$ prior service, $0=$ no prior service). 
Last, to control for a relevant individual difference variable with respect to the effects of leadership development, we included motivation to lead (Chan \& Drasgow, 2001), defined as "an individualdifferences construct that affects a leader's or leader-to-be decisions to assume leadership training, roles, and responsibilities and that affect his or her intensity of effort at leading and persistence as a leader" (482). Motivation to lead would thus likely influence leaders engagement in and benefit from the mentoring and classroom interventions. Further, Chan and Drasgow (2001) demonstrated that the affective-identity dimension of motivation to lead is associated with leader efficacy with a large effect size $(\beta<.50)$.

For parsimony in our survey instrument, we used only the 9-item affective-identity scale as a control. Affective-identity motivation to lead proposes that some leaders lead because they see themselves as a prototypical leader as a central aspect of their identity, and are, thereby, driven to lead and receive satisfaction by leading others. The other two components of motivation to lead, socionormative and noncalculative, were not used as they have been shown to either be weakly related or unrelated to leader efficacy (see Chan \& Drasgow, 2001; Hendricks \& Payne, 2007). Participants responded to items using a 5-point response scale ( $1=$ strongly disagree; $5=$ strongly agree; $\alpha=.80$ ). Example items included "I am definitely not a leader by nature (reverse scored)," "I am the type of person who likes to be in-charge of others," and "I am seldom reluctant to be the leader of a group," and "I usually want to be the leader in the groups that I work in."

\section{RESULTS}

Prior to hypothesis testing, we conducted a series of tests to establish initial and ongoing equivalence between our experimental conditions. For initial equivalence, there were no statistically significant differences between cadets in the treatment group and the comparison group for any of the demographic controls (age, gender, ethnicity, and prior military experience), or for motivation to lead scores. There was a small initial difference in leader efficacy scores. Cadets in the treatment group $(M=72.01, S D=15.05)$ had slightly lower scores than those in the comparison group $(M=76.62, S D=13.29 ; t=2.23, p<.05)$. To account for this slight difference, we tested our model in an ANCOVA controlling for Time 1 leader efficacy scores.

Related to ongoing equivalence, we note that attrition was greater in the treatment condition than in the comparison condition $(t=3.38, p<.05)$. Why this occurred is unclear. It is important to reemphasize, however, that the program was mandatory, and thus, participants did not drop out; rather, they only declined to fill out surveys at later time periods. One potential explanation for the attrition is that the cadets who failed to complete the final surveys were simply unwilling to volunteer the time to do so. Regardless, to assess ongoing equivalence, post hoc analyses conducted across the conditions showed no significant relationships between study attrition and gender $(t=.51, p=.61)$; prior service $(t=.69, p=.49)$; age $(t=-.66, p=.51)$; non-White status $(t=-1.98$, $p=.05)$; initial scores on motivation to lead $(t=-1.17, \mathrm{p}=.24)$; initial scores on leader efficacy $(t=-.94, p=.34)$; or supervisor-rated performance $(t=1.74, p=.08)$. For those cadets in the mentorship program, no demographic, psychological, or performance variable was significantly associated with discontinuing the program. ${ }^{2}$

\section{Hypotheses Testing}

Correlations and descriptive statistics for the variables can be found in Table 1. To evaluate the role of the proposed antecedents of change in leader efficacy, we computed a difference score for the leader efficacy scale across the time points and correlated it with the developmental condition, trust, and the two types of feedback-seeking orientation.

However, because our predictors were significantly intercorrelated with one another, we chose to test the proposed model in a more rigorous multivariate fromework with controls to more accurately represent the unique and interactive effects of our predictors. To do so, we entered condition (treatment vs. comparison), trust, and both positive and negative styles of feedback seeking into an ANCOVA predicting Time 2 leader efficacy along with interactions between condition and each of the three predictors.

Participants' motivation-to-lead scores were entered as controls along with age, gender, prior military experience, and ethnicity. Last, to ensure that the model predicted change rather than overall level, we also included Time 1 leader efficacy

\footnotetext{
${ }^{2}$ Post hoc analyses of those in the mentorship program showed no significant relationships between study attrition and gender $(t=.63, p=.53)$; prior service $(t=.60, p=.80)$; age $(t=-.85$, $p=.39)$; non-White status $(t=-1.04, p=.30)$; initial scores on motivation to lead ( $t=-.16, p=.88$ ); initial scores on leader efficacy $(t=-1.36, p=.19)$; or supervisor-rated performance $(t=1.21, p=.23)$.
} 
TABLE 1

Descriptives and Correlations of Study Variables

\begin{tabular}{|c|c|c|c|c|c|c|c|c|c|c|c|c|c|}
\hline & $M$ & $\mathrm{~S} D$ & Age & Sex & Eth. & $\begin{array}{c}\text { Prior } \\
\text { Service }\end{array}$ & MTL & Trust & $\begin{array}{l}\text { Pos. } \\
\text { FBS }\end{array}$ & $\begin{array}{l}\text { Neg. } \\
\text { FBS }\end{array}$ & $\begin{array}{c}\text { Lead. } \\
\text { Eff. } \\
\text { T1 }\end{array}$ & $\begin{array}{c}\text { Lead. } \\
\text { Eff. } \\
\text { T2 }\end{array}$ & $\begin{array}{l}\text { MD } \\
\text { score }\end{array}$ \\
\hline Age & 21.71 & 1.01 & - & & & & & & & & & & \\
\hline Sex & .20 & .40 & -.11 & - & & & & & & & & & \\
\hline Ethnic minority & .19 & .39 & .09 & .09 & - & & & & & & & & \\
\hline Prior service & .94 & .24 & $.59 *$ & -.08 & .04 & - & & & & & & & \\
\hline Motivation to lead & 3.58 & .54 & -.07 & -.05 & .08 & -.13 & $(.80)$ & & & & & & \\
\hline Trust & 4.34 & .89 & -.14 & -.03 & -.03 & .14 & .13 & $(.88)$ & & & & & \\
\hline Positive feedback seeking & 2.71 & .89 & -.04 & -.14 & -.01 & $.19^{\star}$ & .09 & .09 & (.75) & & & & \\
\hline Negative feedback seeking & 3.39 & 1.03 & -.04 & -.04 & -.08 & .07 & $.17^{*}$ & $.42^{*}$ & $.42^{*}$ & $(.81)$ & & & \\
\hline Leader efficacy $\mathrm{Tl}$ & 74.80 & 14.15 & -.02 & -.03 & -.03 & -.06 & $.46^{\star}$ & .11 & .09 & .09 & $(.96)$ & & \\
\hline Leader efficacy T2 & 75.01 & 13.13 & .07 & -.08 & -.02 & -.09 & $.39^{*}$ & $.27^{*}$ & -.03 & $.19^{*}$ & $.58^{\star}$ & $(.97)$ & \\
\hline MD scores & 7.36 & 1.89 & -.11 & .01 & -.06 & -.10 & .11 & .12 & -.01 & .00 & $.21^{*}$ & $.15^{*}$ & \\
\hline
\end{tabular}

Note. $N=185-193$.

${ }^{*} \mathrm{p}<.05$.

scores as a control (see Table 2). This overall model predicting Time 2 leader efficacy was significant $\left(F(13,171)=11.80, p<.001, \eta^{2}=.45\right)$. Further, when considered jointly, there was support for our hypotheses concerning the main effects of mentorship, trust, and negative feedback seeking. Specifically, as predicted by Hypothesis l, cadets in the mentorship program were more likely to develop leader efficacy $(t(171)=2.34, p<.05)$. In support of Hypothesis 2, higher levels of trust $(t(171)=2.43$, $p<.05)$ were associated with increases in leader efficacy. Additionally, in support of Hypothesis 3 negative feedback seeking $(t(171)=2.36, p<.05)$ was associated with increases in leader efficacy over time.

While the main effects were all positive, assessing Research Questions 1 and 2 produced mixed

TABLE 2

ANCOVA Predicting T2 Leader Efficacy by Condition

\begin{tabular}{lrrrr}
\hline & $\boldsymbol{\beta}^{*}$ & \multicolumn{1}{c}{$\boldsymbol{S E}$} & \multicolumn{1}{c}{$\boldsymbol{t}$} & $\boldsymbol{p}$ \\
\hline Tl Leader efficacy & .45 & .06 & 7.49 & .00 \\
Condition & 21.81 & 9.31 & 2.34 & .02 \\
Age & 1.95 & .92 & 2.12 & .04 \\
Sex & 2.80 & 1.91 & 1.47 & .14 \\
Ethnic minority & .21 & 1.95 & .11 & .91 \\
Prior service & 3.48 & 3.90 & .89 & .37 \\
Motivation to lead & 3.68 & 1.60 & 2.31 & .02 \\
Trust & 4.53 & 1.86 & 2.43 & .02 \\
Positive feedback seeking & -2.35 & .96 & -2.45 & .02 \\
Negative back seeking & 3.98 & 1.36 & 2.36 & .02 \\
Condition Trust & -2.55 & 2.15 & -1.19 & .24 \\
Condition Neg. FBS & -3.14 & 1.66 & -1.89 & .06 \\
$R^{2}$ & .45 & & & .00 \\
\hline
\end{tabular}

Note. All reported betas are unstandardized beta weights. $N=184$. results. We found no evidence that the effects of trust on leader efficacy development differed across conditions (Research Question 1). Specifically, the interaction between condition and trust $(t(171)=-1.19, p=.24)$ was insignificant. Concerning Research Question 2, we found marginal support for the interaction between negative feedback orientation and condition in predicting leader efficacy development $(t(171)=-1.89, p=.06)$. The pattern of this interaction shows a tendency for negative feedback seeking to be associated with positive changes in leader efficacy in the treatment condition $(\beta=.21, p=.08)$, while showing no relationship to leader efficacy development in the comparison condition $(\beta=-.01, p=.88$; see Figure 2).

Although not hypothesized, we should note that significant positive relationships were found be-

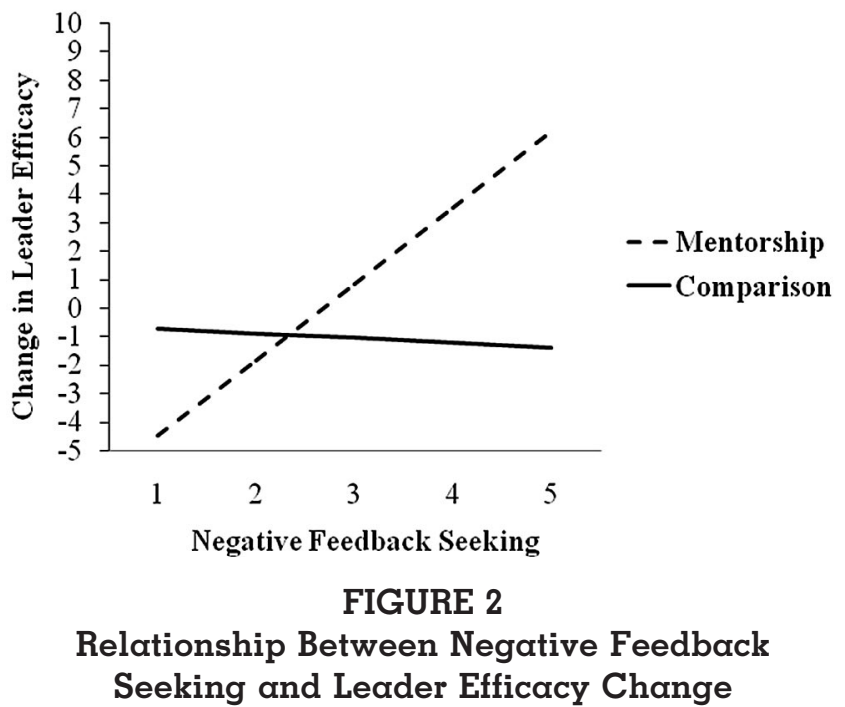


tween leader efficacy development and two of our controls: age $(t(171)=2.17, p<.05)$ and motivation to lead $(t(171)=2.12, p<.05)$. Last, we hypothesized that higher levels of leader efficacy at Time 2 would be associated with higher levels of externally rated leader performance taken 3-4 weeks later (Hypothesis 4). Although the effect size for this relationship was not large, this hypothesis was supported $(r=.15, p<.05)$.

\section{DISCUSSION}

Our results for Hypothesis 1 demonstrated that it is possible to enhance the development of leader efficacy through a semiformal mentorship program. Specifically, the increases we found for leader efficacy scores were significantly higher in the treatment condition than they were in the comparison condition. This result is notable for several reasons: Both groups were already engaged in an intense leader development program at the time of the study; both groups had already spent over 3 years in the military academy's leader development program; the mentorship program served as the only additional intervention that the experimental group received across the time of the study; the experimental design employed a comparison group that received an intervention, rather than a control group.

In developing Hypothesis l, we argued that the mentorship intervention would provide various sources of proven efficacy development techniques including mastery experiences, vicarious learning, social persuasion, and arousal (Bandura, 1997). We believe given the intense developmental experience that these cadets were engaged in at West Point, which is generally full of rich mastery experiences, mentors may have been important in helping cadets make meaning out of their experiences in a focused, one-on-one manner as compared to the less-personalized group setting in the comparison condition. Mentors also likely provided important psychosocial support and served to validate the claims of leadership made by their protégés, helping them to formulate self-construals as capable leaders (DeRue \& Ashford, 2010). To our knowledge, this is the first published report that documents the development of leader efficacy over time, and the first to our knowledge using an experimental field design to test the development of leader efficacy using mentorship as the point of intervention.

In addition, our testing of Hypothesis 2 showed that trust was an important factor in enhancing leader efficacy development across both groups. Achieving the self-concept change needed to build leader efficacy likely requires protégés to be open and willing to discuss and explore their leadership with their mentor or leader, and this requires high levels of trust for the creation of psychological contracts (Robinson \& Morrision, 2000), and positive social exchanges (Cropanzano \& Mitchell, 2005; Richard et al., 2009). These results reinforce that trust is a key factor impacting the success of mentorship programs (Richard et al., 2009).

In support of Hypothesis 3, orientation for tough and critical negative feedback enhanced the development of leader efficacy in contrast to leaders' orientation toward positive feedback, which actually deterred leader efficacy development. These results support earlier findings that individual differences exist for preferring positive or negative feedback (Ashford et al., 2003; Ashford \& Tsui, 1991; VandeWalle, 2003), and further suggest that these preferences may promote or deter leader development (Ashford et al., 2003; DeRue \& Wellman, 2009). These underlying individual differences, such as learning and performance goal orientation, have been identified as being key components of a leader's level of developmental readiness (Avolio \& Hannah, 2008; Hannah \& Avolio, 2010), and our results suggest that they should be further explored as potentially important antecedents of leadership development.

Exploratory results further showed that orientation for negative feedback interacted with the intervention condition, such that for individuals in the treatment condition, negative feedback seeking was associated (marginally) with positive changes in leader efficacy. For those in the comparison condition, there was no relationship between positive feedback seeking and leader efficacy development. This may be because mentoring provides the opportunity for more individualized and intimate disclosures and exchanges between mentor and protégé. In a group classroom training setting, even though some leaders may desire honest and tough feedback, the group setting likely limits such individual feedback, and group facilitators may intentionally restrain from providing negative individual feedback to limit social embarrassment to individuals. Moreover, seeking and receiving negative feedback from a mentor may be considered an important facet of the mentoring process-protégé's are likely to want to know from a trusted adviser what they are doing wrong to correct it.

The findings related to motivation to lead are noteworthy. Chan and Drasgow (2001) previously demonstrated that affective-identity motivation to lead was associated with absolute levels of leader efficacy, and we replicated that relationship here, 
demonstrating that affective-identity at Time 1 was related to both Time $1(r=.46)$ and Time 2 $(r=.39)$ leader efficacy. Here we extend the motivation to lead theory by linking the affectiveidentity dimension to the development of leader efficacy over time. While we used this construct as a relevant control, it appears that the extent individuals feel and see themselves as being a leader influences their engagement in and benefit from leader development experiences, as various scholars have suggested (e.g., Day \& Harrison, 2007; DeRue \& Ashford, 2010; Hannah et al., 2009). The role of motivation to lead in leader development thus warronts future research.

The ultimate goal of most leader development programs is to enhance leader performance. Our analysis of Hypothesis 4 demonstrated that leader efficacy was positively related to externally provided leader performance ratings. Cadets with higher levels of leader efficacy were seen by external raters as higher performers when leading their units. While this suggests that leader efficacy, consistent with prior research (e.g., Chemers et al., 2000; Robertson \& Sadri, 1993), is important to leader performance, we are cautious to interpret this finding as evidence that it was the intervention itself that caused the increased performance. This is because we did not have data on participants' prelevel of performance, and the level of performance across the two conditions at Time 3 was not significantly different. We suggest that future researchers may want to employ an inactive control condition in addition to comparison and treatment conditions to better assess such between group performance effects as well as assess both pre- and postlevels of performance.

\section{IMPLICATIONS}

Although rather preliminary, our finding that a semiformal mentorship training program can have a significant and measurable impact on leader efficacy development when compared to a comparison leadership development program in a setting where much of the focus is on developing leader efficacy, suggests potential for future leadership training and development initiatives in using mentorship to develop leaders. Accumulating findings that mentorship programs can develop leaders, beyond just providing psychosocial support or career advice, would allow organizations to approach leadership development in a more systematic manner, using the role of mentors in the developmental process. In implementing such programs, organizations might consider Cunningham's (1993) suggestions that successful formal mentoring pro- grams require top management support, careful matching of protégés and mentors, training or orientation to mentors, clear roles and responsibilities, and set standards as to the frequency and duration of the sessions. Notably, our results showed that mentorship is important to fostering young leader development. This suggests that mentorship should not be reserved for mid- or senior-level leaders, and that early interventions may serve to start the process of accelerating leader development.

Further, when compared to outsourcing leadership development to expensive programs that typically lack empirical evidence of effectiveness, using mentors may be a more cost-effective and valid method for leader development, provided that the intent of the program is to target developing leader efficacy. Also, by using the organization's own leaders to serve as mentors and to "build the bench" of junior leaders, organizations can simultoneously "develop the developers," as these mentors will likely improve their own leadership through mentoring others, thereby increasing overall leadership capacity (Day, 2000).

Our results can inform practitioners and researchers who seek to design and implement effective mentorship programs. Those who do perhaps should consider both protégé individual differences related to feedback orientation and the importance of building trust between mentors and protégés. As evidenced by the $R^{2}$ shown in Table 2 , the model shown Figure 1 explained a sizeable $45 \%$ of the variance in leader efficacy development. Given the importance of leader efficacy in driving leader engagement and performance (Hannah et al., 2008), we suggest that implementing mentoring programs that focus on the four forms of efficacy development and that build trust and account for relevant individual differences can be important to building organizational leadership capacity. Organizations can assess potential protégés' feedback orientation prior to beginning a mentorship program. If protégés show a propensity for positive versus negative feedback, actions can be taken to attenuate the neutralizing effects of positive feedback orientation. Also, by being aware of these different learning orientations, mentors would be better prepared to frame feedback in ways that are more conducive to development as well as to creating safe contexts for those individuals with more avoidant or performance goal orientations (VandeWalle, 2003).

As noted earlier, the framework of Mayer et al. (1995) suggests that mentors can build trust through demonstrating ability, benevolence, and integrity. This suggests that organizations should 
select individuals with these properties to be mentors as well as to develop such characteristics in their mentors. They could also seek to increase protégé's attributions of these properties in the organization's mentors (e.g., through highlighting the training that their mentors have received and other expert qualifications).

Future research in this area should continue to examine how to best design mentoring interventions and assess their return on development. Future research might examine the length of the mentoring relationship to see if there is a point where additional time in the relationship provides diminishing returns on leader development; here, our team was limited to one academic semester to study the phenomenon. Generally speaking, our results suggest that the more organizations can move away from one-size-fits-all training toward one-on-one mentorships characterized by trust, the more likely those program interventions will be able to take advantage of the developmental readiness of participants in those programs.

\section{LIMITATIONS}

As with any complex field research initiative of this type, there are clear limitations with the current study. First, we were unable to assess the level of quality of the mentors within and across conditions. The West Point faculty are highly experienced and selected as faculty members based on prior demonstrated leadership performance, yet that does not necessarily make them good mentors. Although we randomly assigned cadets to conditions, each cadet was allowed to select his or her own mentor. We intentionally incorporated this into the research design, as prior research has shown that it is important that protégés are able to select an attractive mentor (Krom, 1985; PhillipsJones, 1982), one that may represent an exemplar "possible self" (Lord \& Brown, 2004). But as noted by Johnson (2007), simply being a faculty member of a college or university does not mean that one has the skills to effectively serve as a mentor, and perhaps the same could be said for military officers with significont leadership, but little mentorship experience. While we assume there was some variance in mentor quality as well as group instructor quality, we have no reason to believe there were significant differences across treatment conditions. Nevertheless, incorporating mentor ability should be considered in future research.

Another limitation was the inability to utilize an inactive control condition in addition to the treatment and comparison conditions; our research environment did not allow this because the entire population of cadets was undergoing an intense leader development experience. Therefore, while we believe the hypotheses of this study were subjected to a more rigorous test than they would have using only a control group, the extent of interventions that the comparison group participated in may have significantly reduced the between-group variance. This particularly limited our ability to test for interaction effects. Alternately, future research can attempt to procure larger samples to increase power. Likewise, researchers may wish to include a treatment condition that receives both conditions tested here (classroom instruction and mentorship) given that protégés may significantly benefit from the combined experience where their mentorship experiences could be linked to classroom learning.

Prior research also suggests that the effect of role models on observers' self-efficacy may be influenced by the level of similarity between the role model and the individual on relevant characteristics (Bandura, 1997; Stajkovic \& Luthans, 1998). In the current study, our participants were emerging military leaders with comparatively more leadership experience than typical student samples. They were similar to their mentors in the domain of leadership (i.e., military leadership), but the mentors were significantly more experienced. As such, researchers might examine the effectiveness of $a$ mentorship program where the protégé and mentor are closer together in age or professional status. Such a program may elicit a stronger result in protégé development because the mentors may embody a possible self perceived by protégés to be within closer reach.

In this field study, a number of aspects of the mentorship intervention could have influenced the significant effects observed. For example, the timing of the meetings with the mentor, when the mentorship program was introduced at the Academy, and how participants interpreted being assigned to the mentoring condition are among many other factors may have impacted the findings reported here. One possible confound is that it was not the mentorship experience per se that influenced development in leader efficacy, but rather that development was simply a function of the increased attention those in the treatment condition received. While these alternate explanations cannot be entirely ruled out, it should be noted that the median number of meetings for cadets in the treatment condition was 6-7, while those in the comparison condition met six times. Further, post hoc analyses within the treatment condition showed that neither number of meetings $(r=-.02, p=.90)$ nor satisfaction with the mentor- 
ship program $(r=.10, p=.38)$ was significantly related to leader efficacy development. Further, the intervention included both role model interviews and an essay writing requirement where protégés were asked to reflect upon and write about their mentorship experiences. It may be argued that neither was mentorship per se, but instead actions to enhance the effects of mentorship through deeper processing, and therefore, possibly influenced our findings. Clearly additional research is needed to unpack what works and does not work in such semiformal programs to optimize return on developmental investment.

Consistent with the mentorship research of Eby et al. (2008), the effects that we found here were within Cohen's (1988) small-to-medium effect sizes. Our findings may be interpreted as further evidence of the expected impact that mentorship can have within the workplace, and they are within the realm of previous mentorship research outside the domain of leadership development.

Further, while we assessed two individual difference variables (feedback orientation and motivation to lead) in the current study, future research should consider how other individual differences may influence the linkage between mentorship and leader efficacy. Recent longitudinal research has shown that both positive (i.e., "Big 5") personality traits, such as conscientiousness, as well as negative "dark side" traits, such as diligence (i.e., borderline obsessive-compulsive) both influenced leader development trajectories over a 3-year period (Harms, Spain, \& Hannah, 2011). It is possible that protégé traits may influence mentorship as a leader development intervention. Future research should also consider individual differences proposed in theories of developmental readiness (Avolio \& Hannah, 2008), such as interests and goals, metacognitive ability, self-complexity, and self-awareness, (Hannah \& Avolio, 2010).

Finally, this study was conducted with young military leaders in a highly selective undergraduate military college who may have been more responsive to leader development programs than those in other organizations. Contrarily, as our participants were in an intense developmental experience, the effects may have been attenuated as compared to other populations. Future research should assess whether similar effects occur in adult samples that are from organizations outside of the military context. It is certainly possible that the unique context of the U.S. military may have influenced our effects, thus replication studies using adult samples from a broader range of organizations should be conducted to verify our findings.

\section{CONCLUSIONS}

Although gaps in the mentorship literature persist, this longitudinal experimental study serves as initial evidence that a semiformal mentorship program can serve as an institutional mechanism that enhances leader efficacy development. Specifically, we showed that exposure to mentorship increased protégé leader efficacy and that leader efficacy influenced independent ratings of performance across time. Likewise, our findings suggest that preference for feedback and protégé trust in the mentor influence the development of leader efficacy in the protégé. Perhaps most notably, these findings came from an experiment within an academic institution where leader and leadership development are the raison d'être, suggesting that a mentorship program could potentially be even more effective in contexts where fewer resources are expended toward such development.

\section{REFERENCES}

Allen, T. D., \& Eby, L. T. 2003. Relationship effectiveness for mentors: Factors associated with learning and quality. Journal of Management, 29: 469-486.

Allen, T. D., Eby, L. T., \& Lentz, E. 2006. Mentorship behaviors and mentorship quality associated with formal mentoring programs: Closing the gap between research and practice. Journal of Applied Psychology, 91: 567-578.

Arthur, W., Jr., Bennett, W., Edens, P. S., \& Bell, S. T. 2003. Effectiveness of training in organizations: A meta-analysis of design and evaluation features. Journal of Applied Psychology, 88: 234-245.

Assford, S. J., Blatt, R., \& VandeWalle, D. 2003. Reflections on the looking glass: A review of research on feedback-seeking behavior in organizations. Journal of Management, 29: 773799.

Ashford, S. J., \& Cummings, L. L. 1983. Feedback as an individual resource: Personal strategies of creating information. Organizational Behavior and Human Performance, 32: $370-$ 398.

Ashford, S. J., \& Tsui, A. S. 1991. Self-regulation for managerial effectiveness: The role of active feedback-seeking. Academy of Management Journal, 34: 251-280.

Avolio, B. J. 2007. Promoting more integrative strategies for leadership theory-building. The American Psychologist, 62: 25-33.

Avolio, B. J. 2011 . Full range leadership development. Thousand Oaks, CA: Sage.

Avolio, B. J., Avey, J. B., \& Quisenberry, D. 2010. Estimating the return on leadership development. The Leadership Quarterly, 21: 633-644.

Avolio, B. J., \& Hannah, S. T. 2008. Developmental readiness: Accelerating leader development. Consulting Psychology Journal, 60: 331-347.

Avolio, B. J., \& Luthans, F. 2006. The high impact leader: Moments matter in accelerating authentic leadership development. New York: McGraw-Hill. 
Avolio, B. J., Reichard, R. J., Hannah, S. T., Walumbwa, F. O., \& Chan, A. 2009. 100 years of leadership intervention studies: A meta-analysis. The Leadership Quarterly, 20: 764-784.

Avolio, B. J., Rotundo, M., \& Walumbwa, F. O. 2009. Early life experiences as determinants of leadership role occupancy: The role of parental influence and rule breaking behavior. Leadership Quarterly, 20: 329-342.

Avolio, B. J., Walumbwa, F. O., \& Weber, T. J. 2009. Leadership: Current theories, research, and future directions. Annual Review of Psychology, 60: 421.

Bandura, A. 1997. Self-efficacy: The exercise of control. New York: W.H. Freeman.

Bandura, A., \& Locke, E. A. 2003. Negative self-efficacy and goal effects revisited. Journal of Applied Psychology, 88: 87-99.

Bass, B. M., \& Bass, R. 2008. The Bass handbook of leadership: Theory, research, and managerial applications (4th ed.). New York: Free Press.

Berson, Y., Shamir, B., Avolio, B. J., \& Popper, M. 2001. The relationship between vision, strength, leadership style, and context. Leadership Quarterly, 12: 53-73.

Bono, J. E., \& Ilies, R. 2006. Charisma, positive emotions and mood contagion. Leadership Quarterly, 17: 317-334.

Bowlby, J. 1982. Attachment and loss, vol. 1. Attachment (2nd ed.). New York: Basic Books.

Burke, M. J., \& Day, R. R. 1986. A cumulative study of the effectiveness of managerial training. Journal of Applied Psychology, 71: 232-245.

Button, S. B., Matieu, J. E., \& Zajac, D. M. 1996. Goal orientation in organizational research: A conceptual and empirical foundation. Organizational Behavior and Human Decision Processes, 67: 26-48.

Carver, C. S., \& Scheier, M. F. 1982. Control theory: A useful conceptual framework for personality-social, clinical, and health psychology. Psychological Bulletin, 92: 111-135.

Chan, K. Y., \& Drasgow, F. 2001. Toward a theory of individual differences and leadership: Understanding the motivation to lead. Journal of Applied Psychology, 86: 481-498.

Chemers, M. M., Watson, C. B., \& May, S. T. 2000. Dispositional affect and leadership effectiveness: A comparison of selfesteem, optimism, and efficacy. Personality and Social Psychology Bulletin, 26: 267-277.

Choi, J. N., Price, R. H., \& Vinokur, A. D. 2003. Self-efficacy changes in groups: Effects of diversity, leadership, and group climate. Journal of Organizational Behavior, 24: 357372.

Cohen, J. 1988. Statistical power for the behavioral sciences (2nd ed.). Hillsdale, NJ: Erlbaum.

Collins, D. B., \& Holton, E. F. III 2004. The effectiveness of managerial leadership development programs: A metaanalysis of studies from 1982 to 2001 . Human Resource Development Quarterly, 15: 217-248.

Conway, J. M. 2000. Managerial performance development constructs and personality correlates. Human Performance, 13: 23-46.

Crant, J. M. 2000. Proactive behavior in organizations. Journal of Management, 26: 435-462.

Cropanzano, R., \& Mitchell, M. S. 2005. Social exchange theory: An interdisciplinary review. Journal of Management, 31: $874-900$.
Cunningham, J. B. 1993. Facilitating a mentorship program. Leadership and Organization Development Journal, 14: 1521.

Day, D. V. 2000. Leadership development: A review in context. Leadership Quarterly, 11: 581-613.

Day, D. V., \& Harrison, M. M. 2007. A multilevel, identity-based approach to leadership development. Human Resource Management Review, 17: 360-373.

Day, R., \& Allen, T. D. 2004. The relationship between career motivation and self-efficacy with protégé career success. Journal of Vocational Behavior, 64: 72-91.

DeRue, D. S., \& Ashford, S. J. 2010. Who will lead and who will follow? A social process of leadership identity construction in organizations. Academy of Management Review, 35: 627647.

DeRue, D. S., \& Wellman, N. 2009. Developing leaders via experience: The role of developmental challenge, learning orientation, and feedback availability. Journal of Applied Psychology, 94: 859-875.

Dutton, J. E., \& Dukerich, J. M. 1991. Keeping and eye on the mirror: Image and identity in organizational adaptation. Academy of Management Journal, 34: 517-554.

Dvir, T., Eden, D., Avolio, B. J., \& Shamir, B. 2002. Impact of transformational leadership training on follower development and performance: $\bar{A}$ field experiment. Academy of Management Journal, 45: 735-744.

Dweck, C. S. 1989. Motivation. In A. Lesgold, \& R. Glaser (Eds.), Foundations for a psychology of education. Hillsdale, NJ: Lawrence Erlbaum.

Dymock, D. 1999. Blind date: A case study of mentoring as workplace learning. Journal of Workplace Learning, 11:312317.

Eby, L. T. 2010. Mentorship. In S. Zedack (Ed.), APA handbook of industrial and organizational psychology: 505-525. Washington, D.C.: American Psychological Association.

Eby, L. T., Allen, T. D., Evans, S. C., Ng, T., \& Dubois, D. L. 2008. Does mentoring matter? A multidisciplinary meta-analysis comparing mentored and non-mentored individuals. Journal of Vocational Behavior, 72: 254-267.

Finkelstein, L. M., Allen, T. D., \& Rhoton, L. A. 2003. An examination of the role of age in mentoring relationships. Group and Organization Management, 28: 249-281.

Fraley, R. C., \& Shaver, P. R. 2008. Attachment theory and its place in contemporary personality research. In O. John, \& R. W. Robins (Eds.), Handbook of Personality: Theory and Research (3rd Edition): 518-54l. New York: Guilford Publications.

Garland, H., \& Adkinson, J. H. 1987. Standards, persuasion, and performance: A test of cognitive mediation theory. Group and Organizational Management, 12: 208-220.

Gentry, W. A., Weber, T. J., \& Sadri, G. 2008. Examining careerrelated mentoring and managerial performance across cultures: A multilevel analysis. Journal of Vocational Behavior, 72: 241-253.

Gist, M. E., \& Mitchell, T. R. 1992. Self-efficacy: A theoretical analysis of its determinants and malleability. Academy of Management Review, 17: 183-211.

Hannah, S. T., \& Avolio, B. J. 2010. Ready or not: How do we accelerate the developmental readiness of leaders? Journal of Organizational Behavior, 30: 1-7. 
Hannah, S. T., Avolio, B. J., Luthans, F., \& Harms, P. D. 2008. Leadership efficacy: Review and future directions. The Leadership Quarterly, 19: 669-692.

Hannah, S. T., Campbell, D. J., \& Matthews, M. D. 2010. Advancing a research agenda for leadership in dangerous contexts. Military Psychology, 22: S157-S189.

Hannah, S. T., \& Luthans, F. 2008. A cognitive affective processing explanation of positive leadership: Toward theoretical understanding of the role of psychological capital. In R. H. Humphrey (Ed.), Affect and emotion: New directions in management theory and research, Volume 7 of research in management. Information Age: Charlotte, NC.

Hannah, S. T., Walumbwa, F. O., \& Avolio, B. J. 2008. Leadership efficacy, psychological capital and motivation to lead: Effects on authentic, transformational leadership and performance. Academy of Management Conference, August: Anaheim.

Hannah, S. T., Woolfolk, R. L., \& Lord, R. G. 2009. Leader selfstructure: A framework for positive leadership. Journal of Organizational Behavior, 30: 269-290.

Harms, P. D. in press. Adult attachment styles in the workplace. Human Resource Management Review.

Harms, P. D., Spain, S. M., \& Hannah, S. T. 2011. Leader development and the dark side of personality. Leadership Quarterly, 22: 496-509.

Hendricks, J. W., \& Payne, S. C. 2007. Beyond the Big five: Leader goal orientation as a predictor of leadership effectiveness. Human Performance, 20: 317-343.

House, R. J., \& Aditya, R. N. 1997. The social scientific study of leadership: Quo vadis? Journal of Management, 23: 409473.

Ibarra, H. 1999. Provisional Selves: Experimenting with image and identity in professional adaptation. Administrative Science Quarterly, 44: 764-79l.

Ilgen, D. R., Fisher, C. D., \& Taylor, M. S. 1979. Consequences of individual feedback on behavior in organizations. Journal of Applied Psychology, 64: 349-371.

Johnson, W. B. 2007. On being a mentor. Mahwah, NJ: Lawrence Erlbaum.

Johnson, W. B., \& Andersen, G. R. 2010. Formal mentoring in the U.S. military: Research evidence, lingering questions, and recommendations. Naval War College Review, 63: 113-126.

Kane, T. D., Zaccaro, S. J., Tremble, T. R., Jr., \& Masuda, A. D. 2002. An examination of the leaders' regulation of groups. Small Group Research, 33: 65.

Kark, R., Shamir, B., \& Chen, G. 2003. The two faces of transformational leadership: Empowerment and dependency. Journal of Applied Psychology, 88: 246-255.

Kay, F. M., Hagan, J., \& Parker, P. 2009. Principals in practice: The importance of mentorship in the early stages of career development. Law and Policy, 31: 69-110.

Kram, K. E. 1985. Mentoring at work: Developmental relationship in organizational life. Glenview, IL: Scott Foresman.

Lam, W., Huang, X., \& Snape, E. 2007. Feedback-seeking behavior and leader-member exchange: Do supervisor-attributed motives matter? Academy of Management Journal, 50: 348 364.

London, M. 2002. Leadership development: Paths to self-insight and professional growth. Mahwah, NJ: Erlbaum.
Lord, R. G., \& Brown, D. J. 2004. Leadership Processes and Follower self-identity. Mahwah, NJ: Erlbaum.

Lord, R. G., Foti, R. J., \& DeVader, C. L. 1984. A test of leadership categorization theory: Internal structure, information processing, and leadership perceptions. Organizational Behavior and Human Performance, 34: 343-378.

Lord, R. G., \& Hall, R. J. 2005. Identity, deep structure and the development of leadership skills. Leadership Quarterly, 16: 591-615.

Lord, R. L., Hannah, S. T., \& Jennings, P. L. 2011. A framework for understanding leadership and individual requisite complexity. Organizational Psychology Review, 1: 104-127.

Luthans, F., \& Peterson, S. J. 2002. Employee engagement and manager self-efficacy: Implications for managerial effectiveness and development. Journal of Management Development, 21: 376-387.

Mayer, R. C., \& Davis, J. H. 1995. The effect of the performance appraisal system on trust for management: A field quasiexperiment. Journal of Applied Psychology, 84: 123-136.

Mayer, R. C., Davis, J. H., \& Schoorman, F. D. 1995. An integrated model of organizational trust. Academy of Management Review, 20: 709-734.

McCauley, C. D., \& Van Velsor, E. (Eds.) 2004. Handbook of Leadership Development (2nd ed.). San Francisco: JosseyBass.

McCormick, M. J., Tanguma, J., \& Lopex-Forment, A. S. 2002. Extending self-efficacy theory to leadership: A review and empirical test. Journal of Leadership Education, 1: 2.

Mellor, S., Barclay, L., Bulger, C., \& Kath, L. 2006. Augmenting the effect of verbal persuasion on self-efficacy to serve as a steward: Gender similarity in a union environment. Journal of Occupational and Organizational Psychology, 79: 121129.

Mikulincer, M., \& Nachshon, O. 1991. Attachment styles and patterns of self-disclosure. Journal of Personality and Social Psychology, 61: 321-331.

Mor, N., \& Winquist, J. 2002. Self-focused attention and negative affect: A meta-analysis. Psychological Bulletin, 128: 638662 .

Ortiz-Walters, R. 2009. Mentorship collaborations: A longitudinal examination of the association with job performance and gender. The Journal of Business and Economic Studies, 15: $26-47$.

Paglis, L. L., \& Green, S. G. 2002. Leadership self-efficacy and managers' motivation for leading change. Journal of Organizational Behavior, 23: 215-235.

Paglis, L. L., Green, S. G., \& Bauer, T. N. 2006. Does adviser mentoring add value? A longitudinal study of mentoring and doctoral student outcomes. Research in Higher Education, 47: 451-476.

Payne, S. C., \& Huffman, A. H. 2005. A longitudinal examination of the influence of mentoring on organizational commitment and turnover. Academy of Management Journal, 48: 158-168.

Phillips-Jones, L. 1982. Mentors and protégés. New York: Arbor House.

Prussia, G. E., Anderson, J. S., \& Manz, C. C. 1998. Selfleadership and performance outcomes: The mediating influence of self-efficacy. Journal of Organizational Behavior, 19: 523-538. 
Ramaswami, A., \& Dreher, G. F. 2007. The benefits associated with workplace mentoring relationships. In T. A. Allen, \& L. Eby (Eds.), Blackwell handbook of mentoring: A multiple perspective approach: 211-232. Malden, MA: Blackwell.

Richard, O. C., Ismail, K. M., Bhuian, S. N., \& Taylor, E. C. 2009. Mentoring in supervisor-subordinate dyads: Antecedents, consequences, and test of a mediation model of mentorship. Journal of Business Research, 62: 1110-1118.

Robertson, I. T., \& Sadri, G. 1993. Managerial self-efficacy and managerial performance. British Journal of Management, 4: $37-45$.

Robins, R. W., Noftle, E. E., Trzesniewski, K. H., \& Roberts, B. W. 2005. Do people know how their personality has changed? Correlates of perceived and actual personality change in young adulthood. Journal of Personality, 73: $489-521$.

Robinson, S. L., \& Morrision, E. W. 2000. The development of psychological contract breach and violation: A longitudinal study. Journal of Organizational Behavior, 25: 525-546.

Russell, J. E. A., \& Adams, D. M. 1997. The changing nature of mentoring in organizations: An introduction to the special issue on mentoring in organizations. Journal of Vocational Behavior, 51: 1-14.

Scandura, T. 1998. Dysfunctional mentoring relationships and outcomes. Journal of Management, 24: 449-467.
Stajkovic, A. D., \& Luthans, F. 1998. Self efficacy and workrelated performance: A metaanalysis. Psychological Bulletin, 124: 240-261.

Trapnell, P. D., \& Campbell, J. D. 1999. Private self-consciousness and the five-factor model of personality: Distinguishing rumination from reflection. Journal of Personality and Social Psychology, 76: 284-304.

United States Military Academy 2009. Building capacity to lead: The West Point system for cadet leader development. NY: West Point.

van Knippenberg, D., van Knippenberg, B., De Cremer, D., \& Hogg, M. A. 2004. Leadership, self, and identity. A review and research agenda. Leadership Quarterly, 15: 825-856.

VandeWalle, D. 2003. A goal orientation model of feedbackseeking behavior. Human Resource Management Review, 13: $581-604$.

Wood, R., \& Bandura, A. 1989. Impact of conceptions of ability on self-regulatory mechanisms and complex decision making. Journal of Personality and Social Psychology, 56: 407-415.

Yukl, G., \& Van Fleet, D. D. 1992. Theory and research on leadership in organizations. In M. D. Dunnette, \& L. M. Hough (Eds.), Handbook of Industrial and Organizational Psychology, vol. 3 (2nd ed.): 147-197. Palo Alto, CA: CPP.

Paul B. Lester received his PhD from the University of Nebraska, Lincoln. He is a U.S. Army Captain and the director of research and program evaluation for the U.S. Army's Comprehensive Soldier Fitness program. His research interests include leadership development, courage, and psychological resilience. Correspondence may be sent to paul.lester@us.army.mil.

Sean T. Hannah received his PhD from the University of Nebraska, Lincoln. He is a U.S. Army Colonel and the director of the Center for the Army Profession and Ethic at West Point, the United States Military Academy. His research interests include leadership development, moral development, and self-identity.

P. D. Harms received his PhD from the University of Illinois, Urbana-Champaign. He is an assistant professor of management at the University of Nebraska, Lincoln. His research primarily focuses on leadership and personality development over time.

Gretchen R. Vogelgesang received her PhD from the University of Nebraska, Lincoln. She is a human capital consultant with Federal Management Partners in Washington, DC. Her research focuses on transparent communication between leaders and followers.

Bruce J. Avolio received his $\mathrm{PhD}$ from the University of Akron. He is The Marion B. Ingersoll Professor and executive director, Center for Leadership \& Strategic Thinking in the Foster School of Business, University of Washington. His research focuses on examining how to accelerate leadership development and the return on investment. 
Copyright of Academy of Management Learning \& Education is the property of Academy of Management and its content may not be copied or emailed to multiple sites or posted to a listserv without the copyright holder's express written permission. However, users may print, download, or email articles for individual use. 